\title{
ON THE DEVELOPMENT OF COGNITIVE SKILLS AND BEHAVIOR REGULATION OF FIVE- AND SIX-YEAR-OLD CHILDREN
}

\author{
SOBRE O DESENVOLVIMENTO DE HABILIDADES COGNITIVAS E A REGULAÇÃO \\ DO COMPORTAMENTO DE CRIANÇAS DE CINCO E SEIS ANOS
}

\author{
SOBRE EL DESARROLLO DE LAS HABILIDADES COGNITIVAS Y LA \\ REGULACIÓN DEL COMPORTAMIENTO DE NIÑOS DE CINCO Y SEIS AÑOS
}

\author{
Marfa DEDYUKINA ${ }^{1}$ \\ Maria IVANOVA ${ }^{2}$ \\ Lyudmila POPOVA ${ }^{3}$ \\ Yuri SEMENOV ${ }^{4}$
}

\begin{abstract}
The article analyzes the development of cognitive skills and behavior regulation in five- and six-year-old children. The authors outlined the specifics of the development of cognitive skills and behavior regulation of preschoolers. In Block 1, the authors measured the level of intellectual development. Block 2 included diagnostics of cognitive skills development. In Block 3, the authors evaluated children's understanding of emotions and their own and other people's thoughts and feelings using the diagnostic methods developed for preschool children and adapted by A.N. Veraksa, D.A. Bukhalenkova, and O.V. Almazova. The authors widely used the NEPSY-II neuropsychological diagnostic complex's subtests to assess the mental development of children aged 3 to 16 . The authors devised the norms for developing cognitive skills and behavior regulation adapted for a particular Russian region. The obtained results of the study can be used as the basis for planning correctional and developmental activities with preschool children.
\end{abstract}

KEYWORDS: Nonverbal intelligence. Working memory. Inhibitory control.

RESUMO: O artigo analisa o desenvolvimento de habilidades cognitivas e regulação do comportamento em crianças de cinco e seis anos. Os autores delinearam as especificidades do desenvolvimento de habilidades cognitivas e regulação do comportamento de préescolares. No Bloco 1, mediu-se o nível de desenvolvimento intelectual. O Bloco 2 incluiu diagnósticos de desenvolvimento de habilidades cognitivas. No Bloco 3, avaliou-se a

1 M.K. Ammosov North-Eastern Federal University (NEFU), Yakutsk - Russia. Associate Professor of Preschool Education Department. ORCID: https://orcid.org/0000-0003-1537-4809. E-mail: marfa.dedyukina@yandex.ru

${ }^{2}$ M. M.K. Ammosov North-Eastern Federal University (NEFU), Yakutsk - Russia. Associate Professor of Preschool Education Department. ORCID: https://orcid.org/0000-0002-2707-4523. E-mail: maria.kimovna.ivanova@yandex.ru

3 M.K. Ammosov North-Eastern Federal University (NEFU), Yakutsk - Russia. Associate Professor of Preschool Education Department. ORCID: https://orcid.org/0000-0003-1990-7158. E-mail: lyudmila.v.popova@yandex.ru

${ }^{4}$ Institute for Humanitarian Research and Problems of Indigenous Peoples of the North (SBRAS), Yakutsk Russia. Head of Scientific and Educational Center of the Academy of Sciences of the Republic of Sakha. ORCID: https://orcid.org/0000-0002-8766-3936. E-mail: yuri.ivanovich.semenov@yandex.ru

RPGE- Revista on line de Política e Gestão Educacional, Araraquara, v. 25, n. 3, p. 2340-2360, Sep./Dec. 2021. e-ISSN: 1519-9029 DOI: https://doi.org/10.22633/rpge.v25i2.15926 
compreensão pelas crianças de suas emoções e pensamentos e sentimentos e os de outras pessoas usando métodos de diagnóstico desenvolvidos para crianças pré-escolares e adaptados por Veraksa, Bukhalenkova e Almazova. Os autores usaram subtestes do complexo de diagnóstico neuropsicológico NEPSY-II para avaliar o desenvolvimento mental de crianças de 3 a 16 anos e criaram as normas para desenvolvimento de habilidades cognitivas e regulação do comportamento adaptadas para determinada região russa. Os resultados podem ser usados como base para o planejamento de atividades correcionais e de desenvolvimento com crianças em idade pré-escolar.

PALAVRAS-CHAVE: Inteligência não verbal. Memória de trabalho. Controle inibitório.

RESUMEN: El artículo analiza el desarrollo de las habilidades cognitivas y la regulación de la conducta en niños de cinco y seis años, describiendo los aspectos del desarrollo de las habilidades cognitivas y la regulación del comportamiento de los niños en edad preescolar. El Bloque 1 midió el nivel de desarrollo intelectual. El Bloque 2 incluyó diagnósticos del desarrollo de habilidades cognitivas. El Bloque 3 evaluó la comprensión de los niños sobre las emociones, los pensamientos y sentimientos propios y ajenos utilizando métodos de diagnóstico desarrollados para niños en edad preescolar. Los autores utilizaron las subpruebas del complejo de diagnóstico neuropsicológico NEPSY-II para evaluar el desarrollo mental de niños de 3 a 16 años, idearon las normas para desarrollar las habilidades cognitivas y la regulación del comportamiento adaptadas a una región rusa. Los resultados se pueden utilizar como base para planificar actividades correccionales y de desarrollo con niños en edad preescolar.

PALABRAS CLAVE: Inteligencia no verbal. Memoria de trabajo. Control inhibitorio.

\section{Introduction}

Preschool age is the time when a child's cognitive sphere undergoes significant changes. The development of cognitive functions is crucial for preparing for school. The needs of preschoolers trigger the development of their psyche. The most important of them are the need for communication, which helps the child to accumulate social experience, the need for external impressions, which ensures the development of cognitive abilities, and the need for motion, which enables the child to master a set of various skills and abilities.

During our activity, we face various problems. To solve them, we have to search for information constantly. Human cognitive skills are an instrument of understanding the world around us. This is our ability to acquire, store, and transform information. Cognitive skills (abilities) are one of the basic resources of a person, ensuring their autonomous, proactive, and productive life. Several studies confirm that cognitive abilities determine how successful the person will be in their life. Therefore, creating educational technologies that ensure the 
effective development of cognitive skills in older preschoolers is relevant for teachers and educators.

The research examined the contradiction between the generally accepted and obvious fact that cognitive skills and regulatory functions act as the main means of socialization and readiness of children to study at school and the fact that the content of cognitive skills and regulatory functions has not been thoroughly examined for children aged 5 to 7 years old. This study fills this gap.

\section{Literature review}

Cognition is a complex formation consisting of at least two components that are inextricably intertwined. The first component includes information consisting of separate facts and events of our world and the thought processes required for receiving and processing information. In other words, this includes: what interests the child and what they choose to learn from the world around them; how the child receives information, that is, the methods and means of cognition; how the child processes information: how they operate with it at different age stages — systematizing, collecting, forgetting, and organizing it.

Specific cognitive processes may also be called cognitive development (from the Latin "cognitio"-knowledge, cognition, study, and awareness) (PIAGET, 2008). Swiss philosopher and psychologist Jean Piaget, who revealed a certain ability of a person to reflect the world around them more accurately and to perform logical operations with images that occur during the interaction with the outside world, created the theory of cognitive development, and he considered this ability the basis of thought processes.

In practice, however, cognitive development is the conscious improvement of thought processes. Cognitive abilities may be considered an indicator of intelligence (intelligence quotient, IQ - a measure of intelligence), which describes the individual's ability to understand and substantiate concepts and ideas. One way to assess cognitive performance is to break it down into two components: verbal and nonverbal intelligence. Verbal intelligence implies the person has some vocabulary, can perceive information, reason, and analyze information obtained during communication. Nonverbal intelligence requires the understanding of relationships and the analysis of how phenomena coexist with each other. Preschool children develop these abilities and learn relevant skills in practice.

Gardner (2000) developed the theory of multiple intelligences, in which one of the constituent elements represented interpersonal intelligence - the ability to recognize and 
differentiate feelings, views, and intentions of others. Honeywill (2015) and other psychologists pointed to the difference between intelligence measured using IQ tests and social intelligence.

Having analyzed the works of Rubinstein (2000), and Ozerov and Solovyeva (1999), we found out that cognitive abilities are interpreted as specific properties of the effective reflection and comprehending the external and internal world through sensations, perception, memory, attention, imagination, and thinking.

One of the main characteristics of human activity is cognitive ability. Each person is intrinsically a scientist, a researcher, who seeks to understand, anticipate, and control the world of their personal experiences to interact with it more effectively. Science begins with the systematization of facts, and so does the cognitive activity of any person. Like a scientist, a person observes events and formulates concepts or constructs to structure the perceived phenomena. Thus, according to Kelly (1955), the classification of events takes the form of construction.

Studying the research problem, we examined the publications on the children's readiness for school. They evaluated the child's starting school competencies for successful learning (SNOW, 2006). Researchers identified the following domains of school readiness:

1) Linguistic knowledge and skills, including speaking and understanding speech;

2) Literacy basics (knowledge of some phonological features and alphabet);

3) Basic mathematical knowledge and skills, including classification, serialization, the idea of space and time, and the knowledge of numbers;

4) Cognitive abilities related to academic achievement and the development of the child;

5) The level of social and emotional development related to early learning and school performance (SNOW, 2006).

According to Druzhinin (2001), Maslennikov (2004), and Syrnikova (1999), human cognitive abilities (personality traits and the development of cognitive abilities) are the basis of a person's productive life and determine the person's further achievements and success in life. Thus, according to the studies reviewed, cognitive abilities usually manifest themselves and are assessed only in human activity. Many Russian and international authors link cognitive abilities to productive intellectual activity.

In his research, describing the changes in modern children, Feldstein (2011) noted major differences in their perception, attention, memory, consciousness, thinking, the essence 
of their orientations, and other characteristics. According to him, the main difference is a sharp decline in the cognitive development of preschoolers. At the same time, Feldstein claims that the value of intelligence is increasing. Education, high achievement, health, and good looks are becoming especially important qualities for children and their parents.

Regulatory functions are one of the main factors ensuring successful social, intellectual, and professional adaptation of the individual in life. Therefore, we found it viable to study the early stages of the formation of this function, its determination, and individual variations in the course and as the result of its development (PULKKINEN, 1996).

One of the most widely used approaches to understanding regulatory functions in children is the model developed by Miyake et al. (2000). According to this model, the neuropsychological basis for mastering one's behavior consists of cognitive skills used for purposeful problem solving and adaptive behavior in new situations. Researchers refer to these skills as executive functions and divide them into three main components: 1) working memory; 2) attention flexibility or switching; 3) inhibitory control or inhibition. These components are related to each other, but they may also be considered independently. Therefore, they called this model Unity with Diversity (MIYAKE et al., 2000).

International publications on psychology use the term regulatory functions when discussing the study of behavior regulation mechanisms. Regulatory functions help the person to control thoughts and actions, focusing on the stimulus connected with solving a problem or completing a task and ignoring distractions. In fact, regulatory functions is an umbrella term for various cognitive skills that allow one to behave adaptively and flexibly in new situations (ALMAZOVA; BUKHALENKOVA; VERAKSA, 2016).

The regulation includes four interrelated systems: attention, cognitive flexibility, goal setting, and information processing. Attention implies selectivity, monitoring, and tracking one's actions and behavior. Cognitive flexibility is the ability to switch from one response to another, move to and cope with new actions, use different strategies, and process information. Goal setting implies the ability to set a goal, plan your actions, and determine the steps required to achieve it. Information processing is associated with the efficiency of performing new complex tasks (ANDERSON, 2002).

Frye, Zelazo and Palfai (1995) argue that general cognitive abilities underlie the regulatory functions and the development of the theory of consciousness. Kloo and Perner (2003) have another point of view: They assume that the same process - inhibitory controldetermines the tasks aimed at studying the theory of consciousness and regulatory functions. The authors consider the classical experiment of Wimmer and Perner (1983) and argue that 
this task requires the person to use the following abilities: 1) to keep two possibilities in mind; 2) to suppress the dominant response, and 3) to elicit a nondominant response.

Some researchers believe that the development of behavior regulation largely determines children's success at school (AARON et al., 2008; BLAIR; RAZZA, 2007; CUTTING et al., 2009). However, there are no common factors that affect the above phenomena. Thus, most researchers believe that to understand mental states one should have certain regulatory functions: to keep different points of view or potential realities in mind, switch flexibly between them, and restrain one's position to understand other people's opinions. However, studying the formation of the child's behavior regulation, its mechanisms, and individual variations in the course of this process remains an acutely relevant and unresolved task.

\section{Materials and methods}

We studied the development of cognitive skills and behavior regulation in older preschoolers within the "Growing up with Yakutia" subproject of the Federal Project "Growing up with Russia" in collaboration with the Russian Academy of Education and the Faculty of Psychology of Moscow State University.

The research goal was to obtain full information about the individual psychological characteristics of the children in Yakutia. For this purpose, we carried out comprehensive scientific research into the factors affecting their formation, psychophysiological development, and cognitive and noncognitive factors that determine academic and life success at all stages of education. This research will take several years, but the first results on preschoolers' development are already available.

In total, 14 preschool institutions of the Republic of Yakutia participated in the project. In the future, we are planning to involve as many children as possible, thereby obtaining a sample for the whole Republic. This will enable us to evaluate the development of children in different territories of the Republic, for instance, in Southern and Central Yakutia and the Arctic. To this end, the Laboratory of Childhood was established within the framework of a new project of the "Trust Fund for Future Generations of the Republic of Sakha (Yakutia)". This laboratory aims to introduce scientifically proven and effective tools and mechanisms for the harmonious development of children in the Republic.

In contrast to the Russian project, in addition to psychological and pedagogical research, "Growing up with Yakutia" will research the health of young Yakuts. Preschool 
institutions organize free comprehensive medical examinations to evaluate children's general health and identify their development factors. After analyzing the results, we will receive the information on the children's health and give their parents recommendations on improving their health and preventing diseases. Also, the Laboratory of Childhood will form the analytical basis for developing and implementing scientifically proven and effective tools and mechanisms for the harmonious development of children, their recovery, and the prevention of diseases from an early age. Medical examinations are carried out by the specialists of the North-Eastern Federal University Medical Institute, the Laboratory of Childhood, and the Academy of Sciences of Yakutia. First of all, experts assess the first line of immune defense and immunity in general. A pediatrician and medical specialists analyze children's physical development in line with medical grounds. Kindergarten psychologists carry out an empirical study of cognitive activity in older preschoolers under the supervision of the experts working at the Department of Preschool Education, the Pedagogical Institute of NEFU (DEDYUKINA; IVANOVA, 2020).

In 2020, the study involved 215 senior preschoolers of the Republic of Sakha (Yakutia). The goal of the empirical study was to identify the specifics of the development of cognitive skills and behavior regulation in older preschoolers. To achieve the research goal, we set the following objectives:

1) To determine a set of methods for assessing the cognitive skills and regulatory functions of older preschoolers;

2) To form groups of children participating in the experiment;

3) To evaluate the cognitive skills and regulatory functions of the older preschoolers;

4) To analyze the estimates of cognitive skills and regulatory functions of older preschoolers;

5) To develop recommendations for the development of cognitive skills and regulatory functions of older preschoolers.

To assess the development of regulatory functions, we applied a set of the following methods, which are widely used both in Russian and international practice (ALMAZOVA BUKHALENKOVA; VERAKSA, 2019). The comprehensive diagnostics of older preschoolers included: measuring the level of intellectual development (nonverbal intelligence); diagnostics of the development of regulatory functions (working memory, inhibitory control, and cognitive flexibility); diagnostics of social skills (the child's 
understanding of their own and other people's thoughts and feelings). Psychologists (testers) examined the children individually in their office and recorded the results in the protocol, which were later processed by the specialists from the Moscow State University:

1) To diagnose nonverbal intelligence, we used the methodology "Raven's Colored Progressive Matrices", which included three series with 12 tasks in each. After completing each task, a child got one point. That is, the maximum score was 36 points. This methodology assessed the child's ability to do systematized and rigorous intellectual activity. The child had to understand the connecting relationship elements in the pattern and indicate the right element in the answer field, choosing it from the options given.

2) To assess visual working memory, we conducted the test "Memory for Designs" (NEPSY-II). Five- and six-year-old children received four samples (with four to eight images per field). Points were awarded for content, location, and as a bonus. The maximum score was 120 points. The subtest allowed us to evaluate two aspects of memory: memorizing images and the spatial arrangement of cards in the field. Assessing regulatory functions in preschoolers, we focused on several aspects of memory: a) images, b) spatial location, and c) the combination of the first and second.

3) The method of sentences repetition (NEPSY-II) involves repeating 17 sentences. The stimulus material gradually becomes more complicated: sentences become longer and more complex in structure. Moreover, the sentences were read to the Yakut-speaking children in Russian. The maximum score for completing the task was 34 points.

4) To assess the cognitive inhibitory control, we used the Inhibition method (NEPSY-II), which included two tasks. Task 1 "Naming": the child had to name all the designs in the order they appeared on the card. In Task 2, "Inhibition", the rules changed: when the child saw a circle, they have to say "square", and when they saw a square, they have to say "circle". The child received a set of 40 geometric designs (squares and circles). There was some practice before each stage. The expert calculated the time spent on this task, the number of mistakes, and self-corrections. The maximum score was 20 .

5) To assess the behavioral inhibitory control, we applied the Statue method (NEPSY-II). The expert said to the child: "Let us see if you can stand like a statue holding a flag in your hand. When I say, 'Start', you must stand like a statue with a flag in your hand and closed eyes until I say the word 'Time!' You should not move, even your fingers. 
You cannot open your eyes either. You should be silent. Ready? Close your eyes and keep them closed. Let us start!" Here we recorded movements, opening the eyes, and sounds. The maximum score was 30 points.

6) We assessed cognitive flexibility using the dimensional change card sort (DCCS) method developed for children aged 3 to 9 (FRYE; ZELAZO; PALFAI, 1995). The children got three tasks: a) To sort by color ( 6 cards); b) To sort by shape (6 cards); and c) To sort by frame (12 cards). The maximum was 24 points.

\section{Results}

We conducted the study from February to May 2020, and the article presents the results of the diagnostics of children in the preparatory groups of seven kindergartens in the Republic of Sakha (Yakutia). We assessed their intelligence and volition with the methods widely used in international practice (the subtests of the neuropsychological diagnostic complex NEPSY-II aimed at assessing the mental development of children aged 3 to 16). The advantage of this complex is that it has precise quantitative measurements based on the aged standard. As a result, we could measure the performance levels of different methods and compare them with each other.

Using Tukey's test (the multiple comparison method), we determined the differences in the assessments of regulatory functions in preschoolers. We estimated the norms and, accordingly, the levels of the child development: $\mathrm{M}$ was the mean; SD was the standard deviation; the low level was lower than M-SD; the average level was in the range between [M-SD; M+SD]; and the high level was more than M+SD. Tables 1-6 present the norms.

Table 1 - Nonverbal intelligence - norms (Raven's Progressive Matrices)

\begin{tabular}{|c|c|c|c|c|c|c|c|c|}
\hline \multirow{3}{*}{ Criterion } & \multicolumn{4}{|c|}{$5.0-5.5$ years old } & \multicolumn{4}{|c|}{$5.5-6.0$ years old } \\
\hline & \multicolumn{2}{|c|}{ Boys } & \multicolumn{2}{|c|}{ Girls } & \multicolumn{2}{|c|}{ Boys } & \multicolumn{2}{|c|}{ Girls } \\
\hline & $\mathrm{M}$ & SD & $\mathrm{M}$ & SD & $\mathrm{M}$ & SD & $\mathrm{M}$ & SD \\
\hline Nonverbal intelligence (images) & 20.4 & 6.3 & 20.6 & 6.3 & 20.6 & 6.3 & 20.7 & 6.3 \\
\hline
\end{tabular}

Source: Prepared by the authors 
Table 2 - Visual working memory - norms (Memory for Designs)

\begin{tabular}{|l|c|c|c|c|c|c|c|c|}
\hline \multirow{2}{*}{ Criterion } & \multicolumn{4}{|c|}{$5.0-5.5$ years old } & \multicolumn{4}{c|}{$5.5-6.0$ years old } \\
\cline { 2 - 9 } & \multicolumn{2}{|c|}{ Boys } & \multicolumn{2}{c|}{ Girls } & \multicolumn{2}{c|}{ Boys } & \multicolumn{2}{c|}{ Girls } \\
\cline { 2 - 9 } & $\mathrm{M}$ & $\mathrm{SD}$ & $\mathrm{M}$ & $\mathrm{SD}$ & $\mathrm{M}$ & $\mathrm{SD}$ & $\mathrm{M}$ & $\mathrm{SD}$ \\
\hline Memory for designs (images) & 37.4 & 5.8 & 37.6 & 5.7 & 38.2 & 5.8 & 39.6 & 5.1 \\
\hline Memory for designs (locations) & 17.7 & 5.1 & 16.8 & 5.7 & 17.5 & 5.4 & 18.2 & 5.5 \\
\hline Memory for designs (bonuses) & 18.2 & 12.9 & 17.0 & 11.7 & 19.2 & 13.1 & 21.1 & 13.8 \\
\hline Memory for designs (points) & 73.4 & 21.2 & 71.4 & 20.2 & 74.9 & 21.6 & 78.8 & 21.9 \\
\hline
\end{tabular}

Source: Prepared by the authors

Table 3 - Auditory and verbal memory - norms (sentences repetition)

\begin{tabular}{|l|c|c|c|c|c|c|c|c|}
\hline \multirow{2}{*}{ Criterion } & \multicolumn{3}{|c|}{$5.0-5.5$ years old } & \multicolumn{4}{c|}{$5.5-6.0$ years old } \\
\cline { 2 - 9 } & \multicolumn{2}{|c|}{ Boys } & \multicolumn{2}{c|}{ Girls } & \multicolumn{2}{c|}{ Boys } & \multicolumn{2}{c|}{ Girls } \\
\cline { 2 - 9 } & $\mathrm{M}$ & $\mathrm{SD}$ & $\mathrm{M}$ & $\mathrm{M}$ & $\mathrm{SD}$ & $\mathrm{SD}$ & $\mathrm{M}$ & SD \\
\hline $\begin{array}{l}\text { Reproduction of auditory and verbal } \\
\text { information }\end{array}$ & 17.4 & 3.8 & 17.6 & 3.9 & 18.2 & 4.8 & 19.6 & 5.1 \\
\hline
\end{tabular}

Source: Prepared by the authors

Table 4 - Inhibitory control - norms (Inhibition)

\begin{tabular}{|l|c|c|c|c|c|c|c|c|}
\hline \multirow{2}{*}{ Criterion } & \multicolumn{4}{|c|}{$5.0-5.5$ years old } & \multicolumn{4}{c|}{$5.5-6.0$ years old } \\
\cline { 2 - 10 } & \multicolumn{2}{|c|}{ Boys } & \multicolumn{2}{c|}{ Girls } & \multicolumn{2}{c|}{ Boys } & \multicolumn{2}{c|}{ Girls } \\
\cline { 2 - 10 } & $\mathrm{M}$ & $\mathrm{SD}$ & $\mathrm{M}$ & $\mathrm{M}$ & $\mathrm{SD}$ & $\mathrm{SD}$ & $\mathrm{M}$ & $\mathrm{SD}$ \\
\hline Naming, the time & 49.2 & 13.1 & 47.9 & 14.7 & 44.3 & 10.8 & 44.2 & 10.6 \\
\hline Naming, uncorrected errors & 1.1 & 2.6 & 0.6 & 1.2 & 0.8 & 1.6 & 0.6 & 1.5 \\
\hline Naming, corrected errors & 1.2 & 1.3 & 0.9 & 1.1 & 1.2 & 1.3 & 0.9 & 1.2 \\
\hline Inhibition, time & 65.9 & 17.7 & 68.5 & 17.3 & 61.0 & 17.8 & 59.8 & 17.2 \\
\hline Inhibition, uncorrected errors & 3.9 & 6.6 & 2.8 & 5.5 & 3.8 & 6.8 & 2.6 & 6.1 \\
\hline Inhibition, corrected errors & 2.3 & 2.1 & 2.0 & 1.8 & 2.4 & 2.4 & 1.9 & 1.8 \\
\hline
\end{tabular}

Source: Prepared by the authors

Table 5 - Physical inhibitory control - norms (Statue)

\begin{tabular}{|l|c|c|c|c|c|c|c|c|}
\hline \multirow{3}{*}{ Criterion } & \multicolumn{4}{|c|}{$5.0-5.5$ years old } & \multicolumn{4}{c|}{$5.5-6.0$ years old } \\
\cline { 2 - 9 } & \multicolumn{2}{|c|}{ Boys } & \multicolumn{2}{c|}{ Girls } & \multicolumn{2}{c|}{ Boys } & \multicolumn{2}{c|}{ Girls } \\
\cline { 2 - 9 } & $\mathrm{M}$ & $\mathrm{SD}$ & $\mathrm{M}$ & $\mathrm{M}$ & $\mathrm{SD}$ & $\mathrm{SD}$ & $\mathrm{M}$ & $\mathrm{SD}$ \\
\hline Inhibitory control & 23.4 & 2.8 & 23.6 & 2.7 & 25.2 & 2.8 & 26.6 & 3.1 \\
\hline
\end{tabular}

Source: Prepared by the authors 
Table 6 - Cognitive flexibility - norms (DCCS)

\begin{tabular}{|l|c|c|c|c|c|c|c|c|}
\hline \multirow{2}{*}{ Criterion } & \multicolumn{3}{|c|}{$5.0-5.5$ years old } & \multicolumn{4}{c|}{$5.5-6.0$ years old } \\
\cline { 2 - 10 } & \multicolumn{2}{|c|}{ Boys } & \multicolumn{2}{c|}{ Girls } & \multicolumn{2}{c|}{ Boys } & \multicolumn{2}{c|}{ Girls } \\
\cline { 2 - 10 } & $\mathrm{M}$ & SD & M & M & SD & SD & M & SD \\
\hline Sorting by color & 5.9 & 0.6 & 6.0 & 0.2 & 5.9 & 0.5 & 6.0 & 0.0 \\
\hline Sorting by shape & 5.3 & 1.4 & 5.6 & 1.2 & 5.3 & 1.5 & 5.7 & 0.9 \\
\hline Sorting by frame & 6.9 & 2.4 & 7.5 & 2.5 & 7.5 & 2.6 & 7.9 & 2.4 \\
\hline Total score & 18.1 & 3.2 & 19.0 & 2.9 & 18.6 & 3.4 & 19.6 & 2.6 \\
\hline
\end{tabular}

Source: Prepared by the authors

The authors of NEPSY-II noted that this diagnostic complex is not suitable for all children. A child has to be excluded from the study if they:

1. Underwent another neuropsychological study within six months;

2. Has auditory or visual impairments or is color blind;

3. Has a psychiatric diagnosis, neuropsychological disorders, attention deficit, hyperactivity, or mental retardation;

4. Was born with a very small weight (less than $2.5 \mathrm{~kg}$ );

5. At the time of the study is taking medications that can affect the results (stimulants, antidepressants, antianxiety medications, etc.);

6. In their history of development, there was a loss of consciousness for more than 5 minutes or falling into a coma (the score of 14 on the Glasgow scale), etc.;

7. Has language difficulties or the language of research is not the child's native language (language difficulties do not include articulation issues if this hinders communication with the child).

We did not monitor the fourth, fifth, and sixth conditions. Figures 1-6 shows the average for each kindergarten. 
Figure 1 - The results for the method Raven's colored progressive matrices

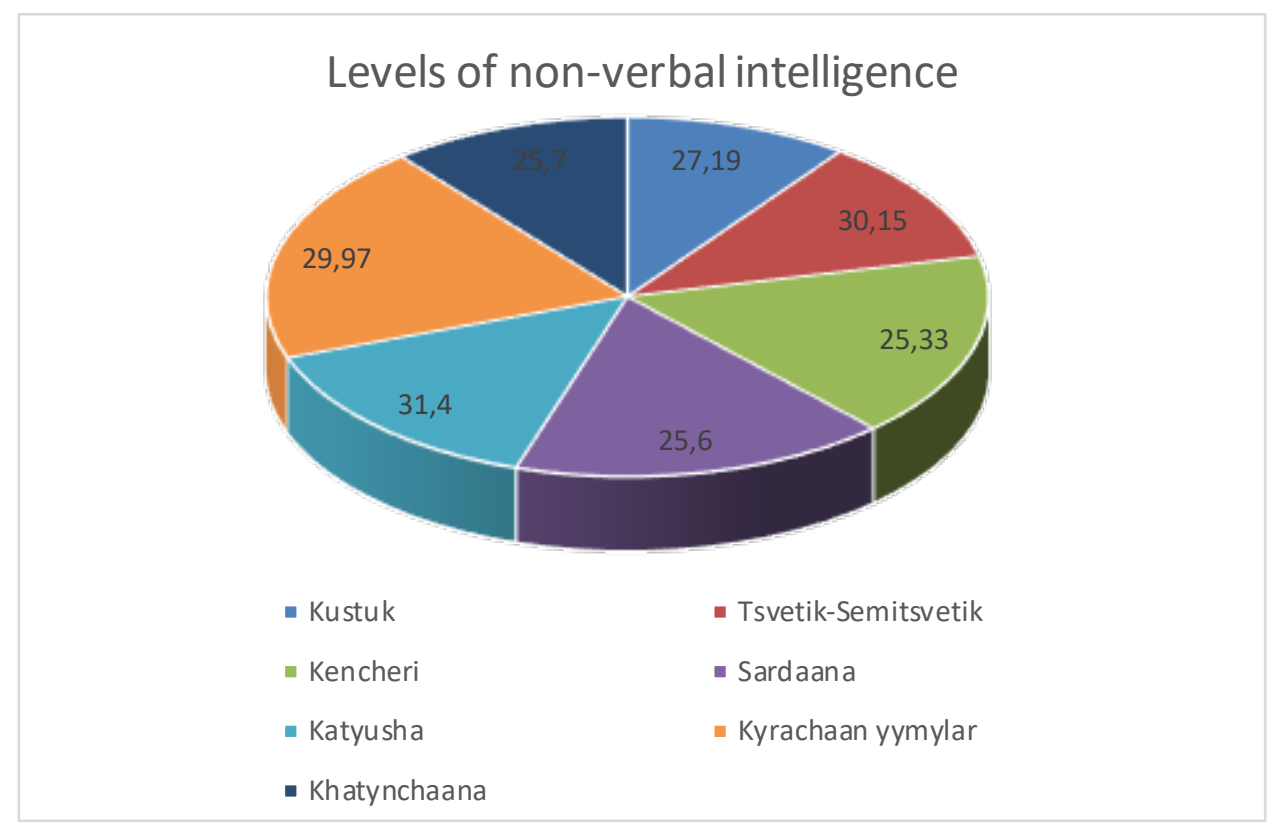

Source: Prepared by the authors

Figure 1 shows that the level of nonverbal intelligence of children in all studied groups is not below the age norm, which indicates that they could participate in the study.

Figure 2 - The results for the Memory for Designs method

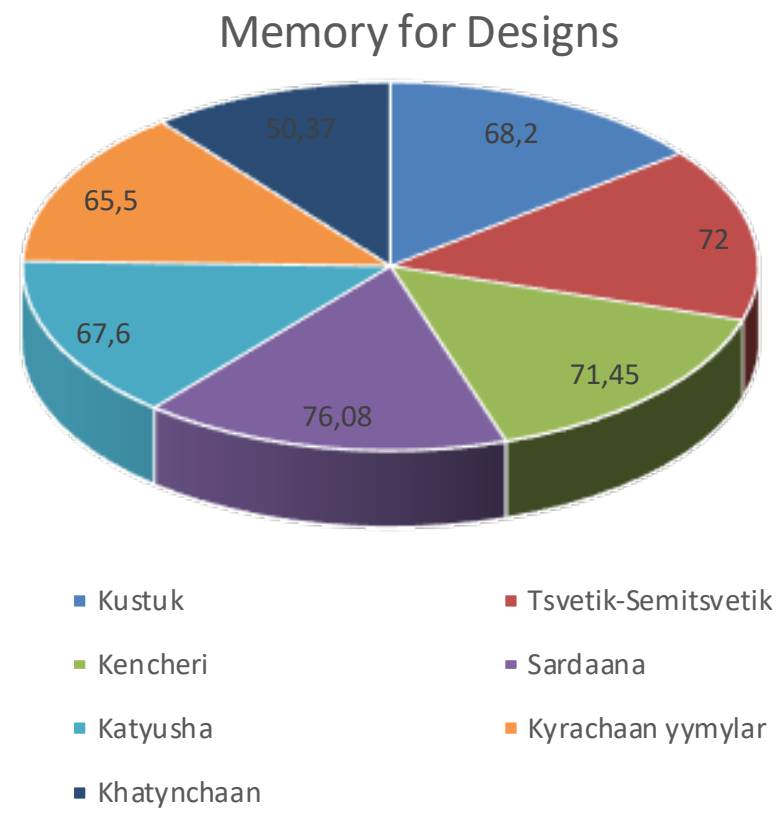

Source: Prepared by the authors

RPGE- Revista on line de Política e Gestão Educacional, Araraquara, v. 25, n. 3, p. 2340-2360, Sep./Dec. 2021. e-ISSN: 1519-9029 
The visual and spatial working memory assessment revealed that the results obtained correspond to the average norm, with the lowest value observed in the kindergarten Khatynchaan, within the standard deviation.

Figure 3 - The results for the Sentences Repetition method (NEPSY-II)

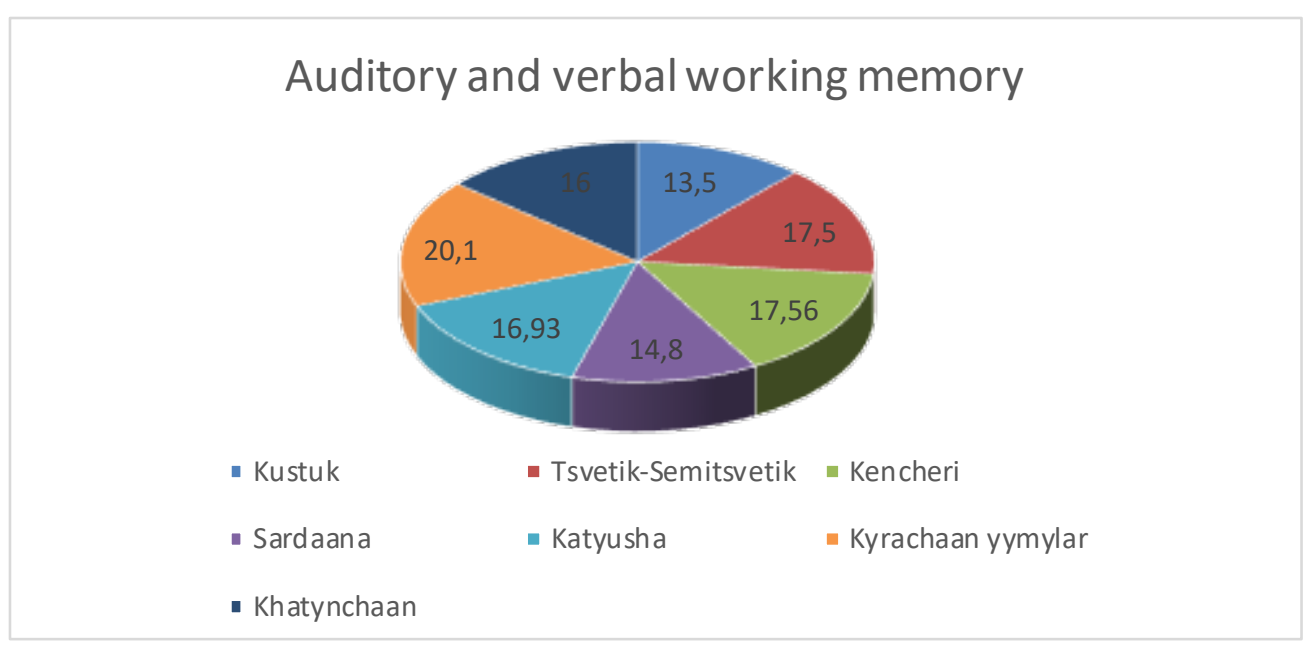

Source: Prepared by the authors

According to Figure 3, the "Sentences Repetition" method had the greatest variation, indicating that the children had very different auditory and verbal working memory levels. This may be because we conducted the experiment in Russian in Russian-speaking and Yakut-speaking groups.

Figure 4 - The results of the Inhibition method

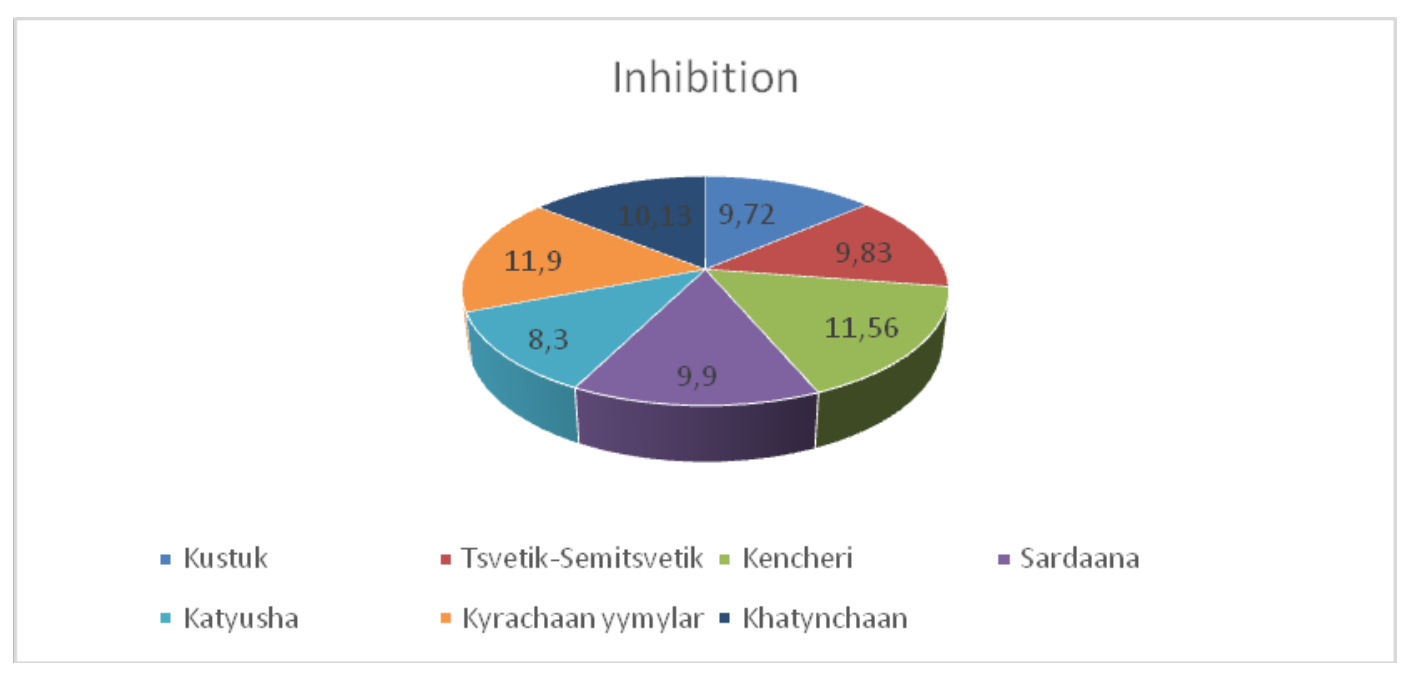

Source: Prepared by the authors

RPGE- Revista on line de Política e Gestão Educacional, Araraquara, v. 25, n. 3, p. 2340-2360, Sep./Dec. 2021. e-ISSN: 1519-9029 
According to the results of the Inhibition method, the children were much better at performing the Naming test than the Inhibition test: they made fewer mistakes and could do it faster.

Figure 5 - The results for the Statue method (NEPSY-II)

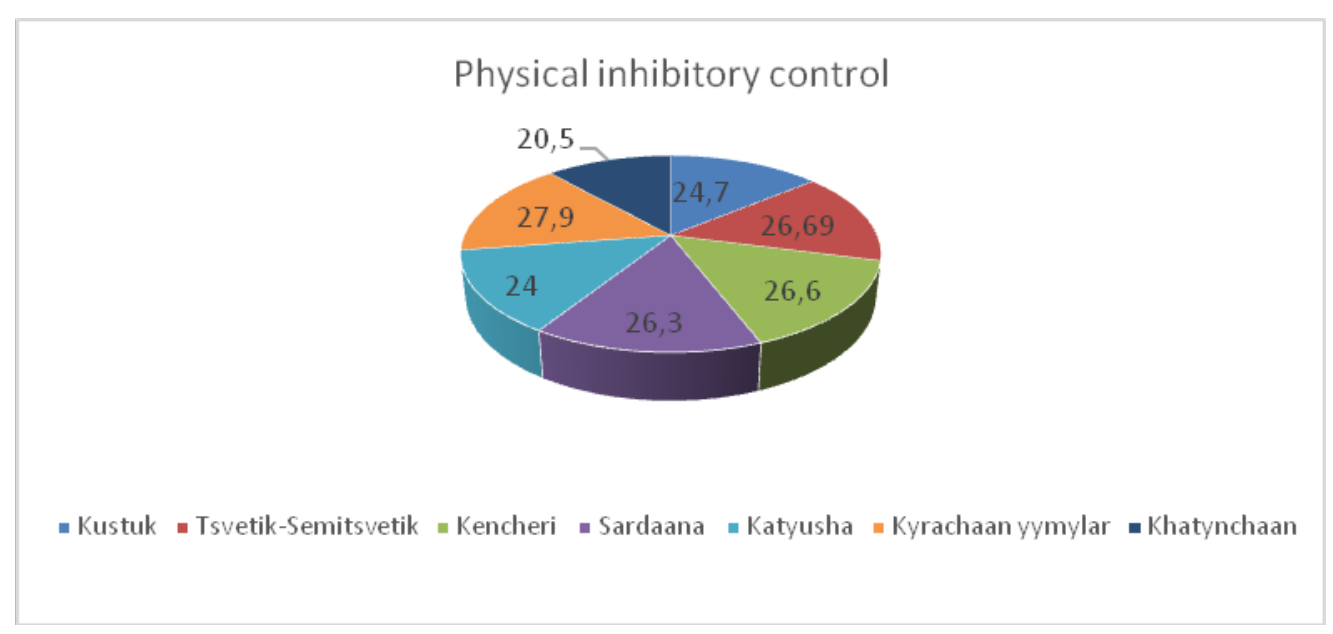

Source: Prepared by the authors

We registered the smallest relative scatter of data in the Statue method. It corresponded to the norm, which indicated the average level of physical inhibitory control.

Figure 6 - The results of the DCCS method

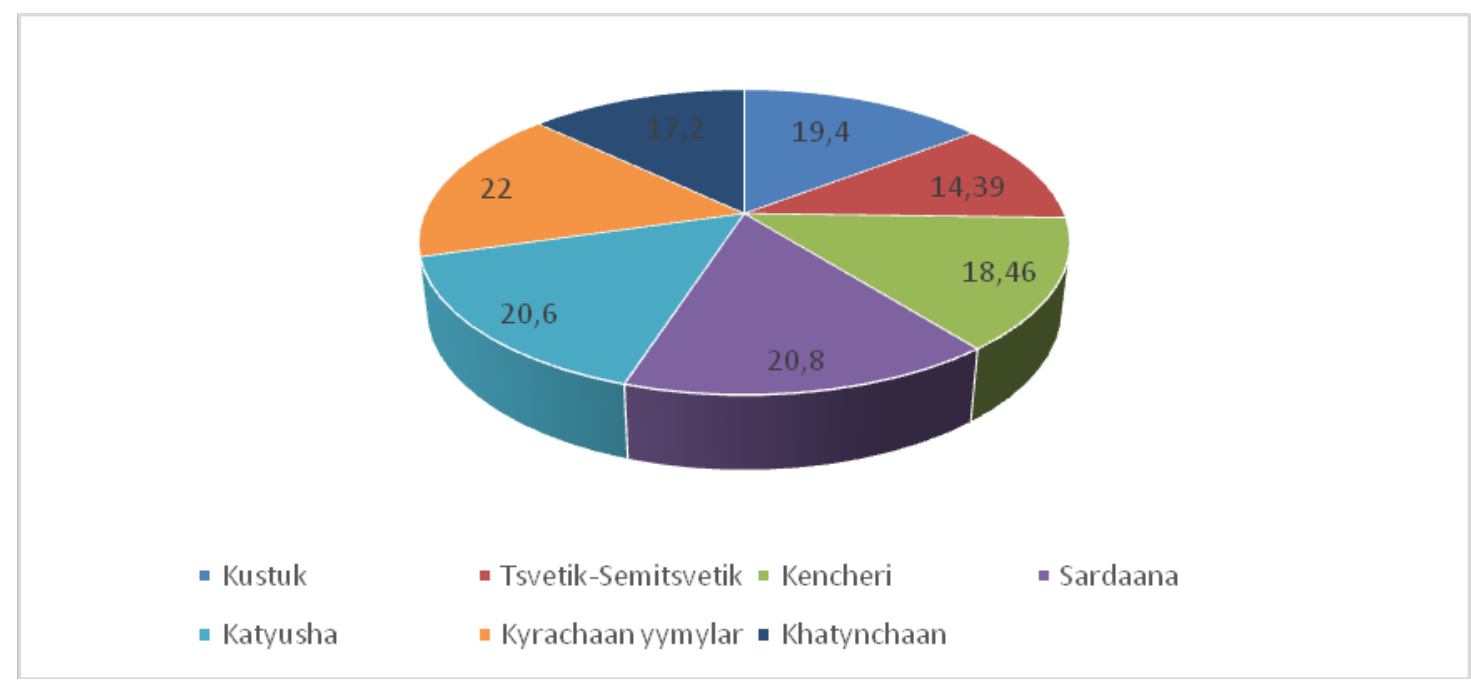

Source: Prepared by the authors

The scatter in data obtained with the Memory for Designs method indicated that the children had different levels of visual memory development. The method revealed some 
specifics: even though the children remembered the details of the image well, they found it harder to remember the spatial arrangement of objects in the picture.

Using the Pearson correlation coefficient, we analyzed the relationship between the studied phenomena (cognitive skills and behavior regulation), establishing the relationship between two variables measured in metric scales on the same sample. We determined cognitive skills and behavior regulation levels in older preschoolers of kindergartens to calculate the correlation coefficient. Table 7 presents the data summary.

The data obtained during the cognitive skills research using Inhibition, Memory for Designs, Statue, and DCCS indicate that $54 \%$ of the children under study had an average ability to analyze and compare to determine and perform actions.

Table 7 - Data summary by the method

\begin{tabular}{|l|c|c|c|c|}
\hline \multirow{2}{*}{ Kindergartens } & Levels & $\begin{array}{c}\text { Nonverbal intelligence } \\
\text { (number of children) }\end{array}$ & $\begin{array}{c}\text { Cognitive skills } \\
\text { (number of children) }\end{array}$ & $\begin{array}{c}\text { Understanding } \\
\text { instructions of adults } \\
\text { (number of children) }\end{array}$ \\
\hline \multirow{3}{*}{ Total, \% } & High & 41 & 25 & 29 \\
\cline { 2 - 5 } & Average & 38 & 54 & 54 \\
\cline { 2 - 5 } & Low & 21 & 21 & 17 \\
\hline
\end{tabular}

Source: Prepared by the authors

The assessment of their nonverbal intelligence demonstrated that $41 \%$ of the children had the high level and $38 \%$ - the average ability to do systematized and planned intellectual activity (Table 8 ). Having examined the children's ability to understand the oral instructions of adults, we concluded that the children had the average ability to perceive and reproduce auditory and verbal information (56\%).

Table 8 - The results of nonverbal intelligence and cognitive skills of older preschoolers

\begin{tabular}{|l|c|c|c|c|c|c|}
\hline \multirow{2}{*}{ Kindergarten } & $\begin{array}{c}\text { Nonverbal } \\
\text { intelligence }\end{array}$ & \multicolumn{4}{|c|}{ Cognitive skills } & \multirow{2}{*}{$\begin{array}{c}\text { Average } \\
\text { score }\end{array}$} \\
\cline { 2 - 7 } & Equals & $\begin{array}{c}\text { Memory for } \\
\text { Designs }\end{array}$ & Inhibition & $\begin{array}{c}\text { Physical } \\
\text { inhibitory control }\end{array}$ & $\begin{array}{c}\text { Cognitive } \\
\text { flexibility }\end{array}$ & \\
\hline Kustuk & 25.7 & 68.2 & 9.72 & 24.7 & 19.45 & 30.51 \\
\hline $\begin{array}{l}\text { Tsvetik- } \\
\text { Semitsvetik }\end{array}$ & 30.15 & 72 & 9.83 & 26.69 & 14.39 & 30.73 \\
\hline Kencheri & 25.33 & 71.45 & 11.56 & 26.6 & 18.46 & 32.51 \\
\hline Sardaana & 25.6 & 76.08 & 9.9 & 26.3 & 20.8 & 33.27 \\
\hline
\end{tabular}




\begin{tabular}{|l|c|c|c|c|c|c|}
\hline Katyusha & 31.4 & 67.6 & 8.3 & 24 & 20.6 & 30.13 \\
\hline $\begin{array}{l}\text { Kyrachaan } \\
\text { yymylar }\end{array}$ & 29.97 & 65.5 & 11.9 & 27.9 & 22 & 31.83 \\
\hline Khatynchaan & 25.7 & 50.34 & 10.13 & 20.5 & 17.2 & 24.60 \\
\hline
\end{tabular}

Source: Prepared by the authors

We determined the following levels of nonverbal intelligence of older preschoolers: 25-30 points: high level; 20-25 points: average level; 15-19 points: low level. In addition, we established the following levels of cognitive skills of older preschoolers: $32-38$ points: high level; 26-31 points: average level; 20-25 points: low level. To determine the correlation between the two indicators measured on a quantitative scale, we calculated the Pearson correlation coefficient, applying the following formula (Equation 1):

$$
r_{x y}=\frac{\sum\left(d_{x} \times d_{y}\right)}{\sqrt{\left(\sum d_{x}^{2} \times \sum d_{y}^{2}\right)}}
$$

The values of the Pearson correlation coefficient are compared with their absolute values. Possible values of the correlation coefficient range from 0 to \pm 1 . The larger the absolute value of $r_{\mathrm{xy}}$ is, the stronger is the correlation between the two values. If $r_{\mathrm{xy}}=0$, then there is no correlation. If $r_{\mathrm{xy}}=1$, then there is a perfect (functional) correlation. If the value of the Pearson correlation criterion is $>1$ or $<-1$, there was an error in the calculations.

In this study, we used the PEARSON Excel function to calculate the Pearson correlation coefficient $r$. This function is applied when estimating the degree of linear dependence between two data sets is necessary. For example, when we calculated the Pearson correlation between two data sets using the PEARSON function, the first array represented the level of nonverbal intelligence and the second the development of children's cognitive skills. Table 9 presents the correlation between cognitive skills and nonverbal intelligence.

Thus, the Pearson correlation coefficient between non-verbal intelligence and cognitive skills was 0.409 , which confirmed a moderate, but statistically significant positive correlation. This result proves that nonverbal intelligence is the basis for mastering one's behavior, that is, self-regulation. 
Table 9 - Calculation of the correlation coefficient between non-verbal intelligence and cognitive skills of the children

\begin{tabular}{|l|c|c|}
\hline Kindergarten & Nonverbal intelligence & Cognitive skills \\
\hline Kustuk & 25.2 & 30.5 \\
\hline Khatynchaan & 25.7 & 24.6 \\
\hline Tsvetik-Semitsvetik & 30.2 & 30.7 \\
\hline Sardaana & 25.6 & 33.3 \\
\hline Katyusha & 31.4 & 30.1 \\
\hline Kencheri & 25.3 & 32.5 \\
\hline Kyrachaan yymylar & 30.0 & 31.8 \\
\hline & & 0.409 \\
\hline
\end{tabular}

Source: Prepared by the authors

We estimated the following levels of understanding oral instructions of adults by older preschoolers: 20-25 points: high level; 15-20 points: average level; 10-15 points: low level. The levels of cognitive skills of older preschoolers were as follows: 32-38 points: high level; 26-31 points: average level; 20-25 points: low level (Table 10). Table 11 presents the relationship between cognitive skills and behavior regulation.

Table 10 - Data on the understanding of oral instructions of adults and cognitive skills of older preschoolers

\begin{tabular}{|c|c|c|c|c|c|c|c|}
\hline \multirow{2}{*}{ Kindergarten } & \multicolumn{2}{|c|}{$\begin{array}{c}\text { Understanding oral } \\
\text { instructions of an } \\
\text { adult }\end{array}$} & \multirow{2}{*}{$\begin{array}{l}\text { Average } \\
\text { score }\end{array}$} & \multicolumn{3}{|c|}{ Cognitive skills } & \multirow{2}{*}{$\begin{array}{l}\text { Average } \\
\text { score }\end{array}$} \\
\hline & $\begin{array}{l}\text { Sentences } \\
\text { Repetition }\end{array}$ & $\begin{array}{l}\text { Cards } \\
\text { sorting }\end{array}$ & & $\begin{array}{l}\text { Memory for } \\
\text { Designs }\end{array}$ & Inhibition & $\begin{array}{c}\text { Physical inhibitory } \\
\text { control }\end{array}$ & \\
\hline Kustuk & 13.5 & 19.5 & 16.5 & 68.2 & 9.72 & 24.7 & 34.2 \\
\hline $\begin{array}{l}\text { Tsvetik- } \\
\text { Semitsvetik }\end{array}$ & 17.5 & 14.4 & 16.0 & 72.0 & 9.8 & 26.7 & 36.8 \\
\hline Kencheri & 17.6 & 18.5 & 18.0 & 71.5 & 11.6 & 26.6 & 27.8 \\
\hline Sardaana & 14.8 & 20.8 & 17.8 & 76.1 & 9.9 & 26.3 & 38.1 \\
\hline Katyusha & 16.9 & 20.6 & 18.8 & 67.6 & 8.3 & 24.0 & 25.4 \\
\hline $\begin{array}{l}\text { Kyrachaan } \\
\text { yymylar }\end{array}$ & 20.1 & 22.0 & 21.1 & 65.5 & 11.9 & 27.9 & 35.1 \\
\hline Khatynchaan & 16.0 & 17.2 & 16.6 & 50.3 & 10.1 & 20.5 & 27.0 \\
\hline
\end{tabular}

Source: Prepared by the authors 
Table 11 - Estimates of the correlation between children's cognitive skills and understanding oral instructions of adults

\begin{tabular}{|l|c|c|}
\hline Kindergarten & Understanding oral instructions of adults & Cognitive skills \\
\hline Tsvetik-Semitsvetik & 16.0 & 30.7 \\
\hline Kustuk & 16.5 & 30.5 \\
\hline Khatynchaan & 16.6 & 24.6 \\
\hline Sardaana & 17.8 & 33.3 \\
\hline Kencheri & 18.0 & 32.5 \\
\hline Katyusha & 18.8 & 30.1 \\
\hline Kyrachaan yymylar & 21.1 & 31.8 \\
\hline & & 0.372 \\
\hline
\end{tabular}

Source: Prepared by the authors

The correlation coefficient between the values "cognitive skills" and "understanding oral instructions of adults" was 0.372 . This result is probabilistic, and we may conclude that developing behavior rules according to the oral instructions of an adult, independently analyzing the reality, and observing the rules are the foundations of behavior regulation.

\section{Conclusions}

Having analyzed the interrelationships of the components of regulatory functions, nonverbal intelligence, and the understanding of oral instructions of an adult, we established that all the groups studied demonstrated a correlation between nonverbal intelligence and behavior regulation. This may be because the neuropsychological basis for mastering one's behavior represents a group of cognitive skills (working memory, cognitive flexibility, and inhibitory control). The probabilistic nature between the estimates of cognitive skills and understanding the oral instructions of an adult may be due to the specifics of speech development.

Thus, this research proved the reliability of this set of methods and allowed us to identify specific norms for girls and boys in two age groups: 1) 5.0-5.5 years old and 2) 5.56.0 years old. These norms will be useful for both researchers and psychologists working in the field of preschool development. We would like to note that the presented set of methods requires further validation and comparison of the results of individual diagnostics of children 
with the assessments carried out by educators and parents, which we intend to do in further studies.

Having analyzed the results obtained, we established a strong correlation between all three components of regulatory functions (working memory, cognitive flexibility, and inhibitory control) and the successful completion of the tasks. In addition to this, we identified three components of the development of regulatory functions in preschool children (designing behavior rules based on oral instructions of an adult, independent analysis of the reality, and observing this rule). In addition, we revealed differences in the completion of individual tasks related to the theory of consciousness in children belonging to different types.

In this research, we revealed the relationship between cognitive skills and regulatory functions in older preschool age. Further study of preschoolers' cognitive skills will help better understand and examine the methods to develop such significant social skills as emotional regulation, establishing a good rapport with peers, and good behavior at school.

\section{REFERENCES}

AARON, P. G. et al. Diagnosis and treatment of reading disabilities based on the component model of reading: An alternative to the discrepancy model of LD. Journal of Learning Disabilities, Dallas, v. 41, n. 1, p. 67-84, 2008. DOI:

https://doi.org/10.1177/0022219407310838

ALMAZOVA, O. V.; BUKHALENKOVA, D. A.; VERAKSA, A. N. The voluntariness in the preschool age: A comparative analysis of various approaches and diagnostic tools.

National Psychological Journal, Moscow, v. 4, n. 24, p. 14-22, 2016. DOI:

https://doi.org/10.11621/npj.2016.0402

ALMAZOVA, O. V.; BUKHALENKOVA, D. A.; VERAKSA, A. N. Diagnostika urovnya razvitiya regulyatornykh funktsiy $\mathrm{v}$ starshem doshkol'nom vozraste [Assessment of the Level of Development of Executive Functions in the Senior Preschool Age]. Psihologija. Žurnal Vysšej školy èkonomiki [Psychology. Journal of the Higher School of Economics], Moscow, v. 16, n. 2, p. 94-109, 2019. Available: https://psy-journal.hse.ru/en/2019-162/292253790.html. Access: 9 Dec. 2021.

ANDERSON, P. Assessment and Development of Executive Function (EF) During Childhood. Child Neuropsychology, Calgary, v. 8, n. 2, p. 71-82, 2002. DOI: https://doi.org/10.1076/chin.8.2.71.8724

BLAIR, C.; RAZZA, R. P. Relating Effortful Control, Executive Function, and False Belief Understanding to Emerging Math and Literacy Ability in Kindergarten. Child Development, Minneapolis, v. 78, n. 2, p. 647-663, 2007. DOI: https://doi.org/10.1111/j.14678624.2007.01019.x 
CUTTING, L. E. et al. Effects of fluency, oral language, and executive function on reading comprehension performance. Annals of Dyslexia, Toronto, v. 59, n. 1, p. 34-54, 2009. DOI: https://doi.org/10.1007/s1 1881-009-0022-0

DEDYUKINA, M. I.; IVANOVA, M. K. Diagnostičeskij instrumentarij izučenija kognitivnoj i èmocional'noj sfer razvitija detej 5-6 let [Diagnostic tools for studying the cognitive and emotional spheres of the development in five and six-year-olds]. Problemy sovremennogo pedagogičeskogo obrazovanija [Problems of Modern Pedagogical Education], n. 67-1, p. 295-298, 2020.

DRUZHININ, V. N. Kognitivnye sposobnosti: Struktura, Diagnostika, Razvitie [Cognitive Abilities: Structure, Diagnostics, Development]. Moscow: Per Sè [PerSe], 2001.

FELDSTEIN, D. I. Glubinnye izmenenija sovremennogo detstva i obuslovlennaja imi aktualizacija psihologo-pedagogičeskih problem razvitija obrazovanija [Deep changes in modern childhood and the resulting actualization of psychological and pedagogical problems of education development]. Vestnik praktičeskoj psihologii obrazovanija [Bulletin of Practical Psychology of Education], Moscow, v. 8, n. 4, p. 3-12, 2011. Available: https://psyjournals.ru/vestnik_psyobr/2011/n4/56243.shtml. Access: 9 Dec. 2021.

FRYE, D.; ZELAZO, P. D.; PALFAI, T. Theory of mind and rule-based reasoning. Cognitive Development, Greensboro, v. 10, n. 4, p. 483-527, 1995. DOI: https://doi.org/10.1016/08852014(95)90024-1

GARDNER, H. E. Intelligence reframed: Multiple intelligences for the 21 st century. Hachette, UK, 2000.

HONEYWILL, R. The man problem: Destructive masculinity in western culture. New York: Palgrave Macmillan, 2015.

KELLY, G. The psychology of personal constructs. New York: Norton, 1955.

KLOO, D.; PERNER, J. Training Transfer Between Card Sorting and False Belief Understanding: Helping Children Apply Conflicting Descriptions. Child Development, Minneapolis, v. 74, n. 6, p. 1823-1839, 2003. DOI: https://doi.org/10.1046/j.14678624.2003.00640.x

MASLENNIKOV, V. A. Development of intellectual abilities of younger schoolchildren. Veliky Novgorod: Novgorod State University, 2004.

MIYAKE, A. et al. The Unity and Diversity of Executive Functions and Their Contributions to Complex "Frontal Lobe" Tasks: A Latent Variable Analysis. Cognitive Psychology, Amherst, v. 41, n. 1, p. 49-100, 2000. DOI: https://doi.org/10.1006/cogp.1999.0734

OZEROV, V. P.; SOLOVYEVA, O. V. Diagnostika i formirovanie poznavatel'nyh sposobnostej: Učebnoe posobie [Diagnostics and the formation of students' cognitive abilities: A textbook]. Stavropol: Stavropol-Servis-Shkola, 1999.

PIAGET, J. Rech i myshlenie rebenka. Moscow: Rimis, 2008. Original title: The language and thought of the child. 
PULKKINEN, L. Female and male personality styles: a typological and developmental analysis. Journal of Personality and Social Psychology, Washington, v. 70, n. 6, p. 12881306, 1996. DOI: https://doi.org/10.1037/0022-3514.70.6.1288

RUBINSTEIN, S. L. Osnovy obŝej psihologii [Fundamentals of general psychology]. St. Petersburg: Piter, 2002.

SNOW, K. L. Measuring school readiness: Conceptual and practical considerations. Early Education and Development, London, v. 17, n. 1, p. 7-41, 2006. DOI: https://doi.org/10.1207/s15566935eed1701_2

SYRNIKOVA, N. A. [On the comprehensive interpretation of intelligence]. In:

SYRNIKOVA, N. A. [Memoirs of Novgorod State University: Collection of articles]. Veliky Novgorod: Novgorod State University, 1999. In Russian.

WIMMER, H.; PERNER, J. Beliefs about beliefs: Representation and constraining function of wrong beliefs in young children's understanding of deception. Cognition, Davis, v. 13, n. 1, p. 103-128, 1983. DOI: https://doi.org/10.1016/0010-0277(83)90004-5

\section{How to reference this article}

DEDYUKINA, M.; IVANOVA, M.; POPOVA, L.; SEMENOV, Y. On the development of cognitive skills and behavior regulation of five- and six-year-old children. Revista online de Política e Gestão Educacional, Araraquara, v. 25, n. 3, p. 2340-2360, Sep./Dec. 2021. eISSN: 1982-5587. DOI: https://doi.org/10.22633/rpge.v25i2.15926

Submitted: $20 / 09 / 2021$

Required revisions: $18 / 10 / 2021$

Approved: 19/11/2021

Published: 08/12/2021 